\title{
Polyethylene Glycol Functionalized Graphene Oxide Nanoparticles Loaded with Nigella sativa Extract: A Smart Antibacterial Therapeutic Drug Delivery System
}

\author{
Mustafa A. Jihad ${ }^{1}$, Farah T. M. Noori ${ }^{1}$, Majid S. Jabir ${ }^{2, *(D)}$, Salim Albukhaty ${ }^{3, *(D)}$, Faizah A. AlMalki ${ }^{4}(\mathbb{D}$ \\ and Amal A. Alyamani ${ }^{5}$ \\ 1 Department of Physics, College of Science, University of Baghdad, Baghdad 10071, Iraq; \\ mscmp101@gmail.com (M.A.J.); farah_t258@yahoo.com (F.T.M.N.) \\ 2 Division of Biotechnology, Department of Applied Science, University of Technology, Baghdad 10066, Iraq \\ 3 Department of Basic Sciences, University of Misan, Maysan 62001, Iraq \\ 4 Department of Biology, College of Science, Taif University, P.O. Box 11099, Taif 21944, Saudi Arabia; \\ fa.ahmad@tu.edu.sa \\ 5 Department of Biotechnology, College of Science, Taif University, P.O. Box 11099, Taif 21944, Saudi Arabia; \\ a.yamani@tu.edu.sa \\ * Correspondence: 100131@uotechnology.edu.iq (M.S.J.); albukhaty.salim@uomisan.edu.iq (S.A.)
}

check for

updates

Citation: Jihad, M.A.; Noori, F.T.M.; Jabir, M.S.; Albukhaty, S.; AlMalki, F.A.; Alyamani, A.A. Polyethylene Glycol Functionalized Graphene Oxide Nanoparticles Loaded with Nigella sativa Extract: A Smart Antibacterial Therapeutic Drug Delivery System. Molecules 2021, 26, 3067. https://doi.org/10.3390/ molecules 26113067

Academic Editor: Raffaello Papadakis

Received: 22 April 2021

Accepted: 15 May 2021

Published: 21 May 2021

Publisher's Note: MDPI stays neutral with regard to jurisdictional claims in published maps and institutional affiliations.

Copyright: (c) 2021 by the authors. Licensee MDPI, Basel, Switzerland. This article is an open access article distributed under the terms and conditions of the Creative Commons Attribution (CC BY) license (https:// creativecommons.org/licenses/by/ $4.0 /)$.

\begin{abstract}
Flaky graphene oxide (GO) nanoparticles (NPs) were synthesized using Hummer's method and then capped with polyethylene glycol (PEG) by an esterification reaction, then loaded with Nigella sativa (N. sativa) seed extract. Aiming to investigate their potential use as a smart drug delivery system against Staphylococcus aureus and Escherichia coli, the spectral and structural characteristics of GO-PEG NPs were comprehensively analyzed by XRD, AFM, TEM, FTIR, and UVVis. XRD patterns revealed that GO-PEG had different crystalline structures and defects, as well as a higher interlayer spacing. AFM results showed GONPs with the main grain size of $24.41 \mathrm{~nm}$, while GONPs-PEG revealed graphene oxide aggregation with the main grain size of $287.04 \mathrm{~nm}$ after loading $N$. sativa seed extract, which was verified by TEM examination. A strong $\mathrm{OH}$ bond appeared in FTIR spectra. Furthermore, UV- Vis absorbance peaks at $(275,284,324$, and 327) nm seemed to be correlated with GONPs, GO-PEG, N. sativa seed extract, and GO-PEG- N. sativa extract. The drug delivery system was observed to destroy the bacteria by permeating the bacterial nucleic acid and cytoplasmic membrane, resulting in the loss of cell wall integrity, nucleic acid damage, and increased cell-wall permeability.
\end{abstract}

Keywords: graphene oxide nanoparticles; polyethylene glycol; Nigella sativa; smart drug delivery system; antibacterial activity

\section{Introduction}

The most promising carbon derivatives in material science are graphene oxide (GO) with excellent physical properties, biocompatibility, and chemical stability [1,2]. In 2004 graphene oxide was first reported as a mono-atomically thick planar layer with twodimensional (2D) [3]. Variety biomedical and physical applications of GO have been documented by research groups such as drug loading and delivery [4]. A number of hydrophilic oxygen-containing functions in GO such as epoxy, hydroxyl, and carboxyl groups, have improved dispersibility in solvents as well as provide reactive sites for more functionalization by specific interactions which led to the evolution of smart nano carrier-based drug delivery system. This system promises to apply drugs to specific bacterial strains [5,6] and used instead of chemotherapy as anti-cancer drugs [7]. Biocompatible drugs are considered suitable to prevent the immune system from phagocytosing GO in the body. Because of its low absorption by the high aqueous solubility and reticuloendothelial system, polyethylene glycol (PEG) is one of these biocompatible polymers [8]. Mediterranean 
region herbs $N$. sativa (black seed) is an active herb used as antibacterial therapy. The seeds of N. sativa contain 36-38\% fixed oils, alkaloids, proteins, and saponin, as well as $0.4-2.5 \%$ essential oil. Unsaturated fatty acids make up most of the fixed oil. Thymoquinone cymene, carvacrol, t-anethole, 4-terpineol, and longifolene were among the major components identified by GC-MS, with percentages of (27.8-57.0\%), (7.18-15.5\%), (5.8-11.6\%), (0.25-2.3\%), $(2.0-6.6 \%)$, and $(1.0-8.0 \%)$, respectively $[9,10]$. In this work, graphene oxide synthesis by Hummers method and the conjugated of PEG-4000 was done by using EDC hydrochloride C6H17N3- $\mathrm{HCl}$ and a catalyst (N-hydroxysuccinimide) for esterification to occur between GO and PEG forming PEGylated graphene oxide (GO-PEG). The N. Sativa-loaded GO-PEG (GO-PEG-N. Sativa) was obtained by loading the GO-PEG through $\pi$-stacking and was then characterized using XRD, FTIR, UV-Vis, Raman, AFM, TEM, and FESEM. Both E. coli and $S$. aureus studied their biological activity by examining their effect on the bacteria's cell-wall morphology, which was observed using SEM. Fluorescence microscopy was used to test the damage that occurred as a result of bacterial DNA using an AO/EtBr staining process. In this study, Flaky graphene oxide (GO)nanoparticles (NPs)were synthesized using Hummer's method and then capped with polyethylene glycol (PEG) for the first time via an esterification reaction, then loaded with Nigella sativa ( $N$. sativa) seed extract. The spectral and structural characteristics of GO-PEG NPs were comprehensively analyzed by XRD, AFM, TEM, FTIR, and UV-Vis to investigate their possible use as a smart drug delivery device against Staphylococcus aureus and Escherichia coli. The drug delivery system was observed to destroy bacteria by permeating the bacterial nucleic acid and cytoplasmic membrane, resulting in the loss of cell wall integrity, nucleic acid damage, and increased cell-wall permeability.

\section{Material and Methods}

\subsection{Reagents and Chemicals}

Natural graphite rod (99.995\%), $\mathrm{KMnO}_{2}(99 \%), \mathrm{NaNO}_{3}(99.5 \%), \mathrm{H}_{2} \mathrm{O}_{2}(32 \%), \mathrm{HCl}$ (37.5\%), EDC hydrochloride $\mathrm{C}_{6} \mathrm{H}_{17} \mathrm{~N}_{3}-\mathrm{HCl}, \mathrm{N}-$ hydroxysuccinimide (98\%) from (SigmaAldrich, St. Louis, MO, USA), $\mathrm{H}_{2} \mathrm{SO}_{4}$, (98\%) from (LOBA Chemie, Maharashtra, India), $\mathrm{NaOH}(99 \%)$ from Dae-Jung, PEG 4000 from HI Media, Diethylether $\left(\mathrm{C}_{2} \mathrm{H}_{5}\right)_{2} \mathrm{O}(98 \%)$ from Thomas Baker, and ethanol $\mathrm{C}_{5} \mathrm{H}_{6} \mathrm{OH}(99.9 \%)$ from Scharlab were used.

\subsection{Synthesis of Graphene Oxide Nanoparticles (GONPS)}

The most economical way used to synthesis GO is Hummer's method. In which $1 \mathrm{~g}$ of graphite rod milling in to form a powder and added with sodium nitrate in sulfuric acid was mix in an ice bath for $45 \mathrm{~min}$. After that $3 \mathrm{~g}$ of $\mathrm{KMnO}_{2}$ was added gradually at $35{ }^{\circ} \mathrm{C}$.

The thick blend stirred for 1 day. $\mathrm{KMnO}_{2}$ is reduced by adding $\left(\mathrm{H}_{2} \mathrm{O}_{2}, 32 \%\right)$. A total of $5 \mathrm{~mL}$ of $(\mathrm{HCl}, 37.5 \%)$ and DI water used to wash the thick blend. The resultant was dried at $75{ }^{\circ} \mathrm{C}$ for $5 \mathrm{~h}$ to get the graphene oxide.

\subsection{Preparations of PEG 4000-Functionalized GO}

The activation of (GO-COOH) was begun by the esterification reaction between the GO carboxylic acid group and the PEG hydroxyl group which is necessary for PEGylation of GO, thus, $120 \mathrm{mg} / \mathrm{mL}$ of $\mathrm{NaOH}$ was dissolved in $20 \mathrm{~mL}$ of DI water and added to $20 \mathrm{~mL}$ of GO suspension, $2 \mathrm{mg} / \mathrm{mL}$, which was sonicated for an hour and stirred for $3 \mathrm{~h}$. The suspension $\mathrm{PH}$ was reduced by adding $3 \mathrm{~mL}$ of $\mathrm{HCl}$, then it was centrifuged twice at $4000 \mathrm{rpm}$ for $30 \mathrm{~min}$ to produce GO carboxylic acid (GO-COOH). The residue was washed with water twice and the $(\mathrm{GO}-\mathrm{COOH})$ was diluted by $10 \mathrm{~mL}$ water. To activate (GO-COOH), $400 \mathrm{mg}$ of EDC and $240 \mathrm{mg}$ of NHS were added to $(\mathrm{GO}-\mathrm{COOH})$, then for (GO-PEG), $1500 \mathrm{mg}$ of PEG4000 was added to the resultant and stirred for $24 \mathrm{~h}$. In the final step, the resultant was centrifuged and washed by DI water. The results of carboxylation and PEGylation conjugation were characterized using FTIR and confirmed using UV-vis. 


\subsection{Loading Nigella sativa (N. sativa) on GONPs-PEG}

After ethanol extraction of N. sativa seed, $2.250 \mathrm{~mL}$ of $N$. sativa oil $(3.33 \mathrm{mg} / \mathrm{mL})$ was loaded on $7 \mathrm{~mL}$ aqueous suspension $(4.28 \mathrm{mg} / \mathrm{mL}$ ) GO-PEG. The N. sativa oil and GO-PEG were stirred for $24 \mathrm{~h}$ at a 1:4 ratio of $N$. sativa oil to GO-PEG. The suspension was centrifuged $\left(10,000 \mathrm{rpm}, 25^{\circ} \mathrm{C}\right)$ for $60 \mathrm{~min}$. and left in the oven for $12 \mathrm{~h}$ at $40^{\circ} \mathrm{C}$ to dry and produce the final sample, which is called GO-PEG-N. sativa.

$$
\text { druge loading content }(\%))=\frac{\text { weight of druge in nanoparticles }}{\text { weight of nanoparticles }} \times 100
$$

\subsection{Antibacterial Activity of GONPs-PEG-N. sativa}

The antibacterial ability of the processed GO-PEG was examined using an agar well diffusion technique against the two bacterial strains E. coli (Gram-negative) and S. aureus (Gram-positive) [11,12]. Before starting the culturing process, $20 \mathrm{~mL}$ of Muller-Hinton $(\mathrm{M}-\mathrm{H})$ was poured to the Petri dishes. A sterile wire loop was used to capture the bacteria from their stock cultures. Following the culturing of the cells, a sterile tip was used to bore six mm-diameter wells in the agar plates $[13,14]$. The different concentrations of the GONPs, GONPs-PEG, and GONPs-PEG- N. sativa $(62.5,125,250,500 \mu \mathrm{g} / \mathrm{mL})$ were added to the boring plates. After culturing, the plates were incubated at $37^{\circ} \mathrm{C}$ overnight. The tests were done in triplicate [15]. To assess how GONPs-PEG- N. sativa affects the growth curve of bacteria, they were cultured on the $\mathrm{M}-\mathrm{H}$ agar plates at $37^{\circ} \mathrm{C}$, the collection freshly cultured plates inoculations composed of $50 \mathrm{~mL}$ of nutrient broth. The bacterial grew until the nutrient broth reached optical density (OD) of 0.1 at $600 \mathrm{~nm}$, which is equivalent to the bacterial concentration of corresponds a bacterial concentration of $10^{8}(\mathrm{CFU} / \mathrm{mL})$. Then, bacterial cultures $(1 \mathrm{~mL})$ were added to the nutrient broth and were supplemented with GONPs, GONPs-PEG, and GONPs-PEG-N. sativa at the $250 \mu \mathrm{g} / \mathrm{mL}$ concentration and incubated at $37^{\circ} \mathrm{C}$ for $12 \mathrm{~h}$ with slight agitation. A spectrophotometer was used to determine bacterial growth by measuring the OD [16].

\subsection{Morphology of Bacterial Strain Using SEM}

The divers in the morphology of the two bacterial strains E. coli and S. aureus were observed using a scanning microscope. Both treated and untreated bacteria cells were centrifuged at $500 \mathrm{rpm}$ and then washed three times using $50 \mathrm{mM}$, phosphate buffer solutions ( $\mathrm{pH}$ 7.3). A thin suspension film was made on a clean silicon wafer slide. They were then air-dried at ambient temperature and then they were fixed using $1 \mathrm{~mL}$ of a fixing buffer. Once they were fixed, the slides were incubated at $37^{\circ} \mathrm{C}$ for $1-2 \mathrm{~h}$, and the water was removed using methanol (ascending grade), dried in the open air, and then fixed on the SEM stubs, and they were coated with gold for $5 \mathrm{~min}$, about $20 \mathrm{~nm}$ of gold was left on the cells surface. SEM (TESCAN, Vega III, Czech Republic) which is a multifunctional instrument that can be used to obtain images of a material's surface structure and morphology was used to examine the gold-coated cells [17]. For TEM analysis, a transmission electron microscope (JEOL Ltd., Tokyo, Japan) with an operating voltage of $80 \mathrm{kV}$ was used. In order to conduct TEM examination, $5 \mathrm{~L}$ drops of aqueous suspensions containing PEG-coated GO NPs were put on carbon-coated copper grids. After $15 \mathrm{~min}$, the excess water was collected by the filter paper, and the samples were left to dry in the open air while TEM images were taken.

\subsection{Detection of Reactive Oxygen Species (ROS)}

The ROS that was released by both treated and untreated bacterial cells were detected using an Acridine orange-ethidium bromide $(\mathrm{AO} / \mathrm{EtBr})$ staining procedure. A fluorescent microscope was used to measure the antibacterial activity of the GONPs, GO-PEG, and GONPs-PEG-N. sativa on the organisms for the study. To distinguish cell viability after treatments an $\mathrm{AO} / \mathrm{EtBr}$ staining procedure was done. A total of $50 \mu \mathrm{L}$ bacterial suspension of both treated and untreated was mixed with $50 \mu \mathrm{L}$ (prepared from $10 \mu \mathrm{g} / \mathrm{mL} \mathrm{AO} / \mathrm{EtBr}$ 
stock solution) and was left for about $2 \mathrm{~min}$. The staining procedure followed, after which a thin film of the mixture was applied on a glass slide and then observed under an immunofluorescent microscope. For the living cells, the Acridine orange-stained fluoresce green while for the dead cells the ethidium bromide-stained fluorescence red [18].

\subsection{Bacterial Adherence Assay}

The cells of the rat embryonic fibroblast were cultured in twelve well tissue culture plates at $1 \times 10^{5}$. These cells were contacted with bacteria strains at a multiplicity of infection (MOI) ratio of 200:1 under the absence and presence of the GONPs, GONPs-PEG, and GONPs-PEG-N. sativa at a concentration of $100 \mu \mathrm{g} / \mathrm{mL}$. The plates were then incubated for $1 \mathrm{~h}$ under a $5 \% \mathrm{CO}_{2}$ incubator at $37^{\circ} \mathrm{C}$. After incubation, they were washed thrice with PBS. PFA was used to fix the cells for $15 \mathrm{~min}$, and later crystal violet stain was used to stain the cells for $15 \mathrm{~min}$.

\subsection{Bacterial Invasion Assay}

A 12 well tissue was also used to grow rat embryonic fibroblast (REF) cells, which were later infected with bacterial strains in the absence and presence of GONPs, GONPs-PEG, and GONPs-PEG-N. sativa at concentration $100 \mu \mathrm{g} / \mathrm{mL}$ for $2 \mathrm{~h}$. The REF cells left after culture media was removed were washed thrice with PBS. A fresh RPMI-1640 medium consisting of gentamicin $100 \mu \mathrm{g} / \mathrm{mL}$ was added and the mixture incubated for $2 \mathrm{~h}$. The cells were then washed thrice with PBS, broken down for 20 min using $0.1 \%$ Triton X-100 at $37^{\circ} \mathrm{C}$. For each well, $10 \mu \mathrm{L}$ was drawn and added to the nutrient agar for bacteria colonies to grow, which were counted after $20 \mathrm{~h}$. The bacteria invasion efficiency was determined as the mean number of bacterial in each well. This bacterial invasion assay was conducted in triplicate [19].

\subsection{Statistical Analysis}

The unpaired t-test was the technique used to analyze our results as allows comparison of experimental groups at a significant $p$-value of $<0.05$ [20].

\section{Results and Discussion}

\subsection{Structural Properties of GO and GO-PEG}

Figure 1 shows XRD patterns for GONPs and GONPs-PEG in the red line. GONPs were showed a sharp peak that appeared at $2 \theta=11.83^{\circ}$ that related to (001) plane with $\mathrm{d}$-spacing $\left(7.76^{\circ}\right)$ and conform the hexagonal structure of GONPs. The blue line showed the functionalization of GONPs-PEG 4000 with a broad peak at $2 \theta=23.38^{\circ}$ with $\mathrm{d}$-spacing (3.8 $\AA$ ) which is results from functionalized while the peak of GONPs disappear because GONPs has an effect on the PEG molecular chain structure in the crystal lattice, disrupting the order of its crystallization. This reduces the crystallinity of PEG and results in an effective PEG to GO Nano-sheets by ester bonding [21]. The indexing of (001) determines by the high score plus program.

\subsection{Morphological Properties of GO, GO-PEG and GO-PEG-N. sativa}

AFM and TEM were used to examine the morphology and size of GONPs, GONPsPEG, and GONPs-PEG-N. sativa, as shown in Figures 2 and 3. Images of GONPs showed graphene sheets with the main grain size of $24.41 \mathrm{~nm}$ which conform to the nanosize of synthesis while images of GONPs-PEG illustrated aggregation of graphene oxide with PEG4000. The main grain size increase with functionalizing to $287.04 \mathrm{~nm}$. As a result of the extraction $N$. sativa seed the main grain size is $257 \mathrm{~nm}$ and it was increased when adding the N. sativa to GONPs-PEG to reach $295 \mathrm{~nm}$. The spherical shape is a domain in the last images with conjugation of extraction seed with polymer, and it was showed a significant difference between GONPs, GONPs-PEG, GONPs-PEG-N. sativa. The GONPs sheets images obtained by TEM were found to be single-layered and wrinkled. The particle size was recorded to less than $100 \mathrm{~nm}$ as viewed in Figure 3. The conjugation of PEG 
to GONPs led to an increase, more than $100 \mathrm{~nm}$, in the size of the nanomaterial. The $N$. sativa seed extraction showed a spherical shape with a size of more than $100 \mathrm{~nm}$ while the designed drug of GONPs-PEG-N. sativa showed tree-like of conjugated polymer with N. sativa.

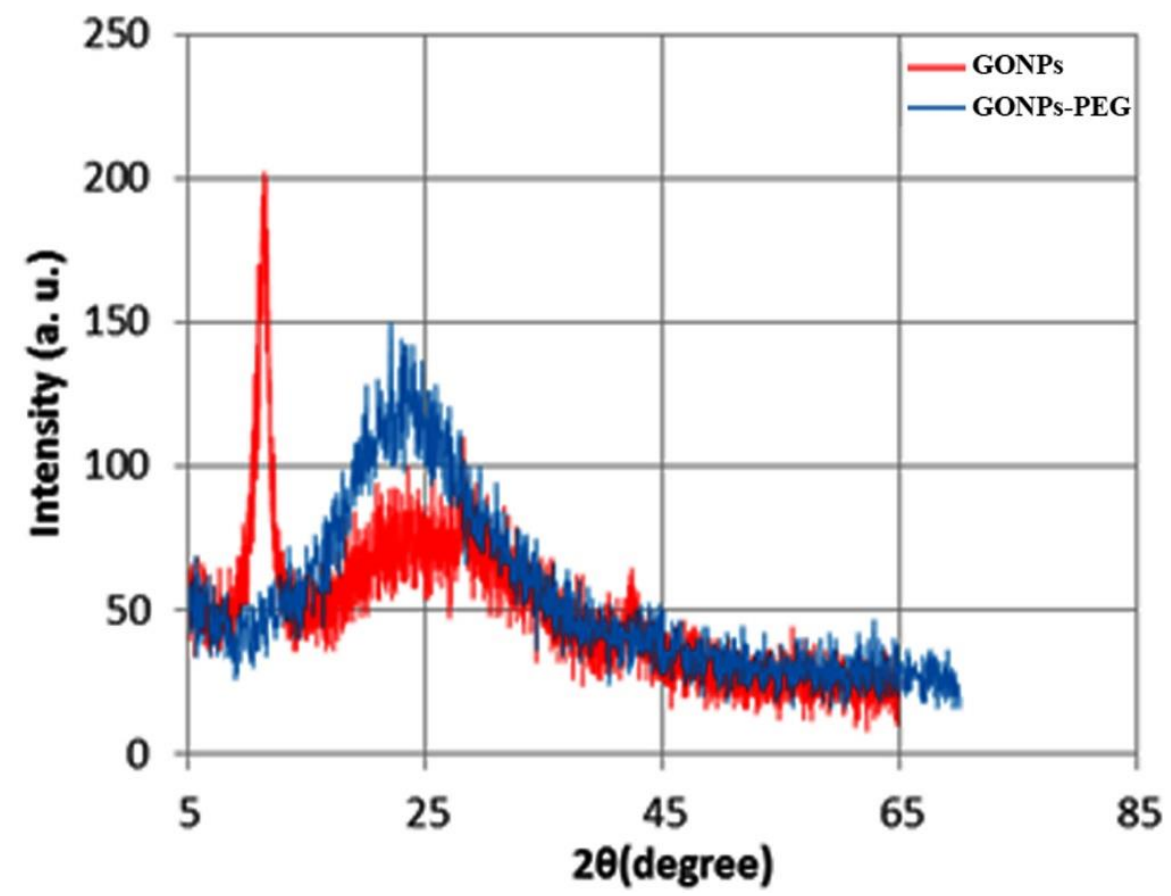

Figure 1. XRD patterns of GONPs and GONPs-PEG.

A

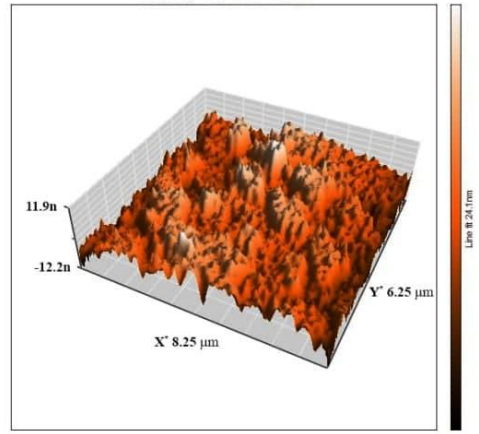

C

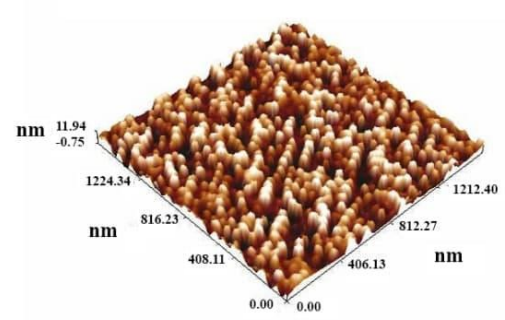

B

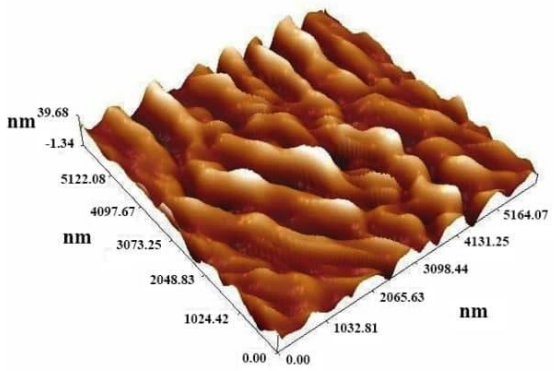

D

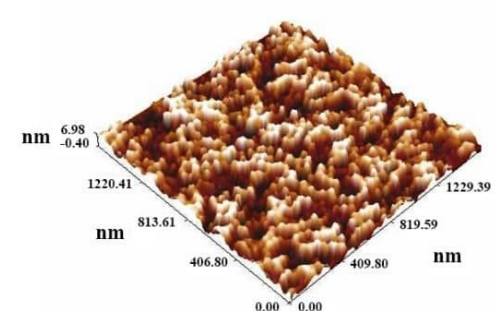

Figure 2. AFM images of (A): GONPs, (B): GONPs-PEG, (C): N. sativa and (D): GONPs-PEG-N. sativa. 
A

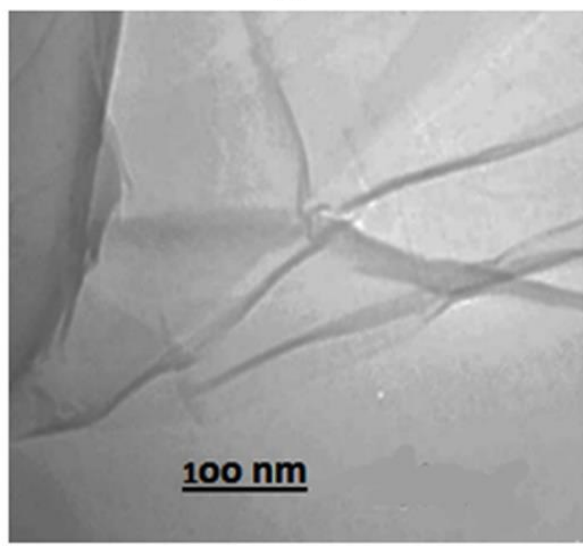

C

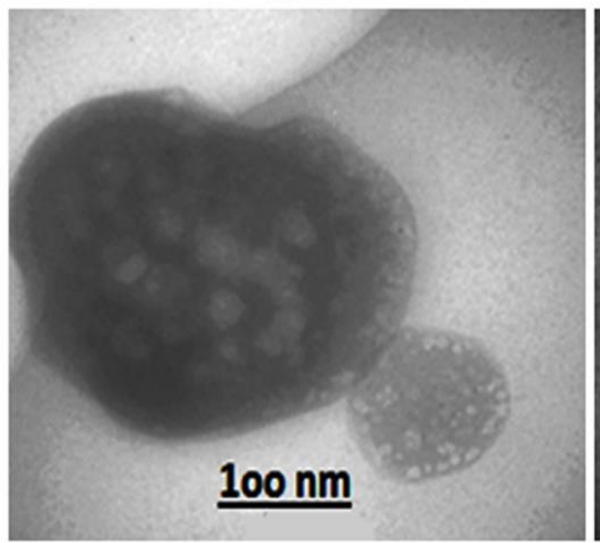

B

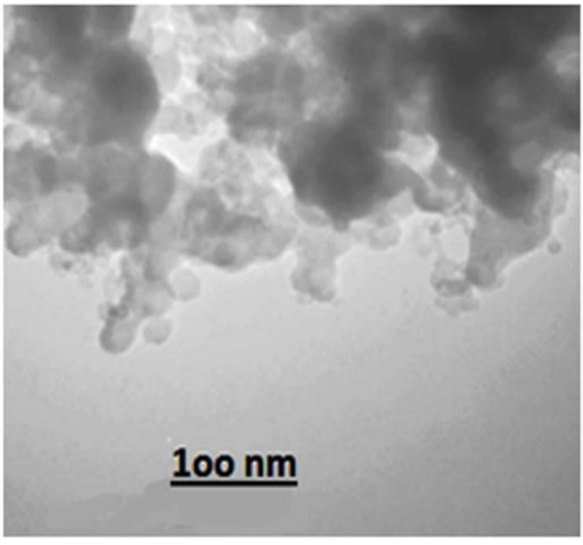

D

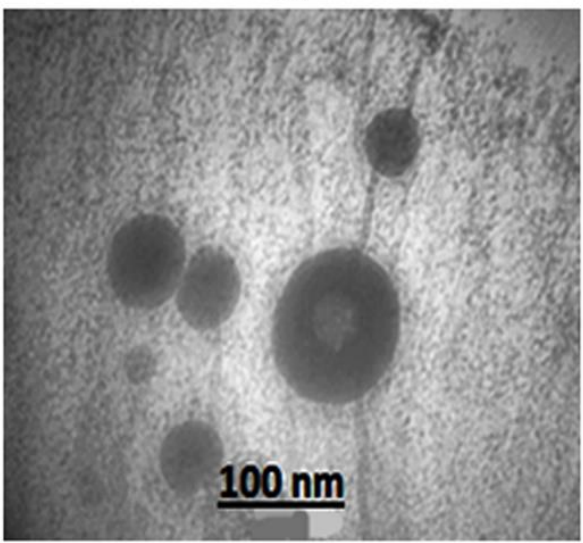

Figure 3. TEM images of (A): GONPs, (B): GONPs-PEG, (C): N. sativa and (D): GONPs-PEG-N. sativa.

\subsection{Chemical Properties of GO-PEG-N. sativa}

FTIR spectroscopy was used to detect changes in the characteristic bands of GONPs and after GONPs-PEG coupling. In general, amino acids are zwitterions that have spectra that contain both primary amine and carboxylate functional groups [22]. Figure 4 shows the FTIR spectrum of GONPs; the peaks at $3338 \mathrm{~cm}^{-1}$ are stretching related to $\mathrm{OH}$, while 1618, 1382 , and $1026 \mathrm{~cm}^{-1}$ are $\mathrm{C}=\mathrm{O}$ groups in carbonyl [-C $\left.(=\mathrm{O})-\right]$ and carboxyl $(-\mathrm{COOH})$ and these results are consistent with a previous study published by Charmi J et al. [23]. The peak at $1724 \mathrm{~cm}^{-1}$ is related to $\mathrm{C}=\mathrm{C}$ and peaks at 1066 and 1382 are related to $\mathrm{C}-\mathrm{O}$ [24]. In the case of GONPs-PEG, the peak at $3338 \mathrm{~cm}^{-1}$ was shifted to $3427 \mathrm{~cm}^{-1}$ and the appearance of $\mathrm{C}-\mathrm{H}$ at $3920 \mathrm{~cm}^{-1}$ proved the conjunction of GONPs to PEG. C=C, C-O, and C=O were found at 1641, 1390, and $1107 \mathrm{~cm}^{-1}$, respectively [25]. The FTIR pattern of $N$. sativa extract was shown in Figure 5, which shows a broad and strong band at approximately $3209 \mathrm{~cm}^{-1}$, which represented the stretching vibration of $\mathrm{O}-\mathrm{H}$ in the hydroxyl groups of hydrogen bonds [26]. The region between $1771 \mathrm{~cm}^{-1}$ and $621 \mathrm{~cm}^{-1}$ is may be assigned to C-O stretching vibrations. The small bands at 578,563 , and $621 \mathrm{~cm}^{-1}$ were attributed to the out-of-plane bending vibrations of $\mathrm{C}-\mathrm{H}$ in the benzene derivative. The Greenline illustrates the loading drug GONPs-PEG-N. sativa, and the OH stretching of GO-PEG is shifted to $3745 \mathrm{~cm}^{-1}$ while the peaks $2854-2924 \mathrm{~cm}^{-1} \mathrm{C}-\mathrm{H}$ stretch (Alkane), which is also appeared at $1516 \mathrm{~cm}^{-1}$. The region between $756 \mathrm{~cm}^{-1}$ and $439 \mathrm{~cm}^{-1}$ is may be assigned to C-O stretching vibrations (ester) [27]. 


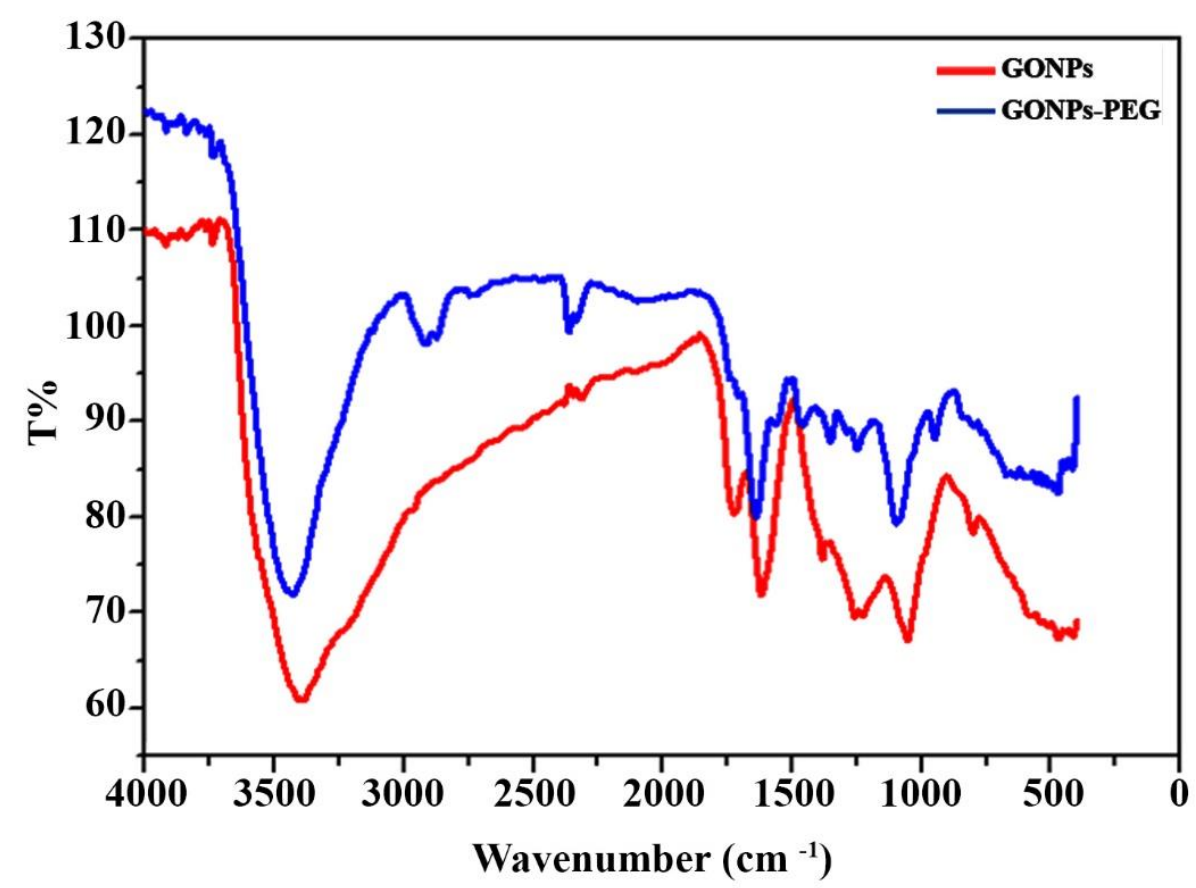

Figure 4. TIR spectrum of GONPs and GONPs-PEG.

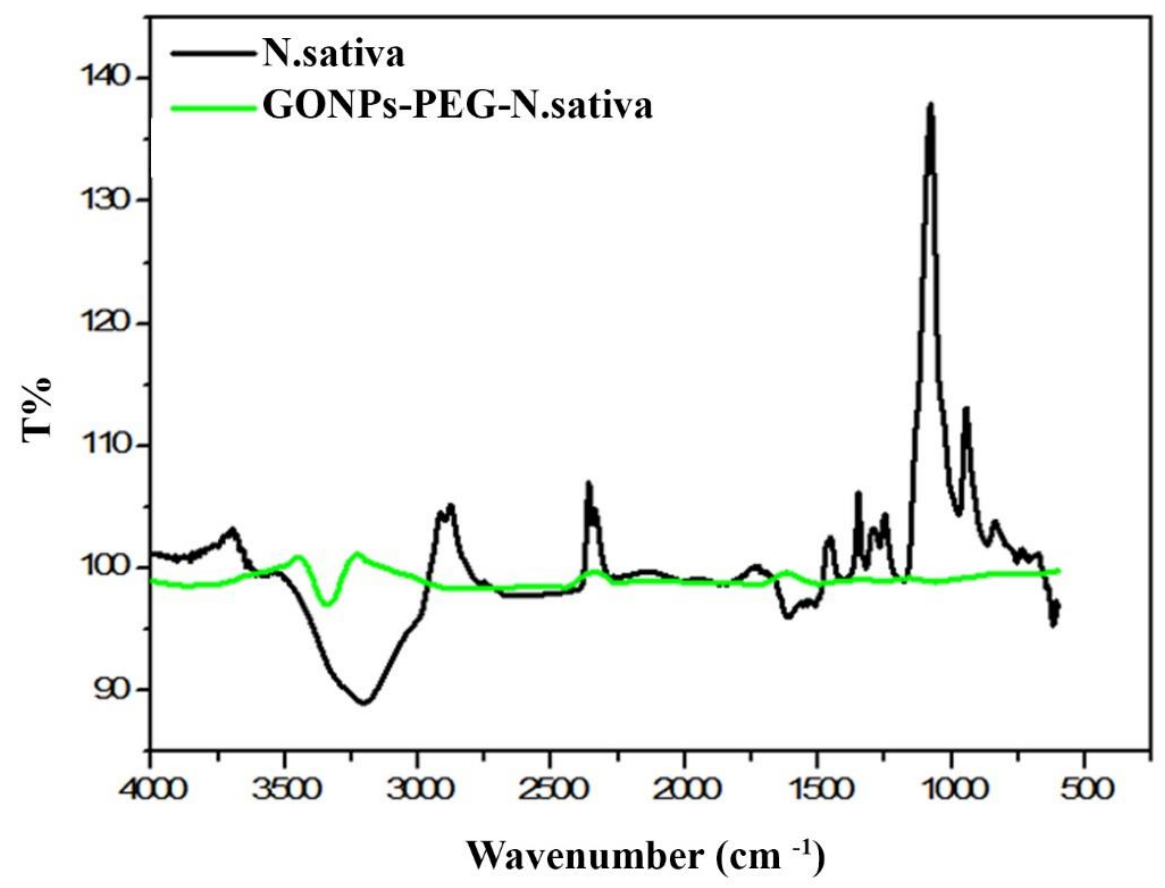

Figure 5. FTIR spectrum of N. sativa extract and GONPs-PEG-N. sativa.

\subsection{Optical Properties of GO-PEG-N. sativa}

In UV-vis spectra of GONPs and GONPs-PEG (Figure 6), the red line indicates the GONPs spectra at $275 \mathrm{~nm}$ which represent the absorption bands that related to electronic transition $\pi-\pi^{*}$ for $C-C$ (aromatic rings) and transition $n-\pi^{*}$ for $C=O$ in the GO. The blue line represents the GONPs-PEG that shifted to $284 \mathrm{~nm}$ which is confirmed the synthesis of GONPs-PEG [28]. The black line illustrates the spectra of $N$. sativa and the green line represented GONPs-PEG-N. sativa. In N. sativa showed a sharp peak at $324 \mathrm{~nm}$ while in GONPs-PEG-N. sativa the peak shifted to $327 \mathrm{~nm}$. 


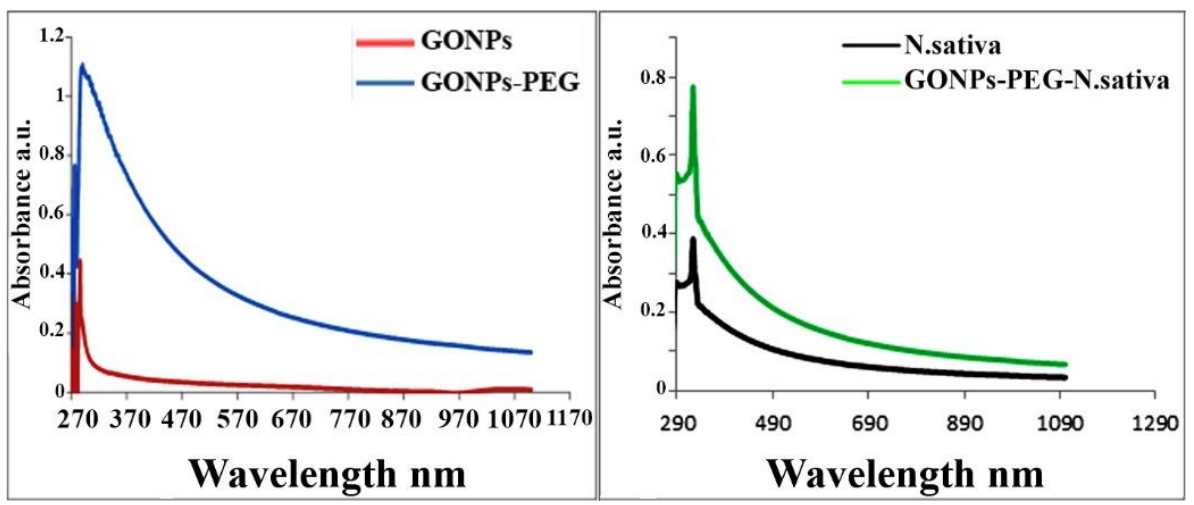

Figure 6. UV-vis absorption spectrum of GONPs, GONPs-PEG, N. sativa, GONPs-PEG-N. sativa.

\subsection{Antibacterial Activity of GO, GO-PEG, GO-PEG-N. sativa}

The antibacterial effects of pure gold nanoparticles are viewed differently by researchers. Many researchers conclude that pure nanogold particles have no antibacterial properties or that the results are minimal. According to a study conducted by Zhang et al., gold nanoparticles have no or only slight bactericidal effects at high concentrations [29]. The effect of $15 \mathrm{~nm}$ gold nanoparticles on the antibacterial activity of gentamicin was investigated by Burygin et al. using a variety of methods at various concentrations of gentamicin and particles, but no differences in antibacterial activity of gentamicin and gentamicin-gold nanoparticle mixtures were found within the range of experimental errors. [30].

On the other hand, several studies have shown that Metal Oxide NPs have antibacterial properties against $S$. aureus and E. coli [31,32]. The antibacterial of GONPs, GONPs-PEG, GONPs- PEG-N. sativa was analyzed using S. aureus and E. coli. The inhibition zone after organism's exposure to different concentrations of GONPs, GONPs-PEG, GONPsPEG-N. sativa were measured and illustrated in Figure 7. The result showed that the GONPs-PEG-N. sativa was found to be effective more than GONPs and GONPs-PEG and the results are concentration-dependent manner. GONPs-PEG-N. sativa produced a zone of inhibition with a diameter approximately $30 \mathrm{~mm}$ against $E$. coli and $36 \mathrm{~mm}$ against $S$. aureus. A zone of inhibition was produced at the concentration $(500 \mu \mathrm{g} / \mathrm{mL})$ with a diameter of almost $36 \mathrm{~mm}$ against $S$. aureus and a diameter of $30 \mathrm{~mm}$ against $E$. coli. The results demonstrated that the effect of the nanoparticles depended on the concentration. The micro-organisms demonstrated resistance to external agents because their outer membrane has a bacterial structure [33]. The GONPs, GONPs-PEG, GONPs-PEG-N. sativa effect on the growth of the organisms was time-dependent, with more growth noticeable after $12 \mathrm{~h}$. of treatment as shown in Figure 8. Taken together, the inhibitory effect of GONPsPEG-N. sativa was observed to be more than of GONPs, GONPs-PEG as proven by the statistical analysis. 

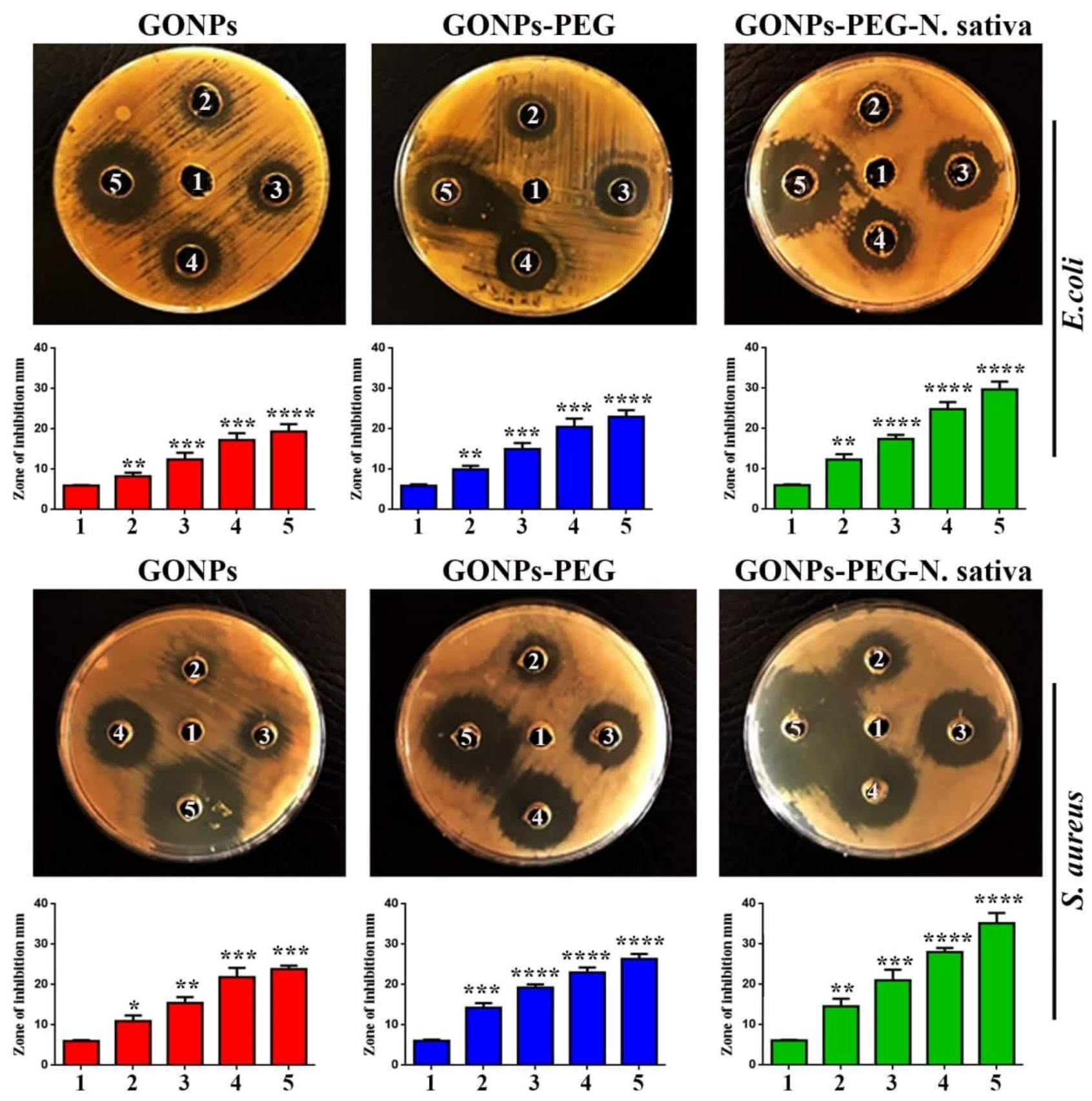

Figure 7. Anti-bacterial activity of GONPs, GONPs-PEG, and GONPs-PEG-N. sativa against S. aureus and E. coli. (1): control untreated bacterial strains. The inhibited zones of bacterial growth for both strains are illustrated when exposed to variety concentrations as follows; (2): $62.25 \mu \mathrm{g} / \mathrm{mL},(3): 125 \mu \mathrm{g} / \mathrm{mL},(4): 250 \mu \mathrm{g} / \mathrm{mL},(5): 500 \mu \mathrm{g} / \mathrm{mL}$. The data are shown as the mean \pm SD. ${ }^{*} p<0.05,{ }^{* *} p<0.01{ }^{* * *} p<0.001$, and ${ }^{* * *} p<0.0001$. 

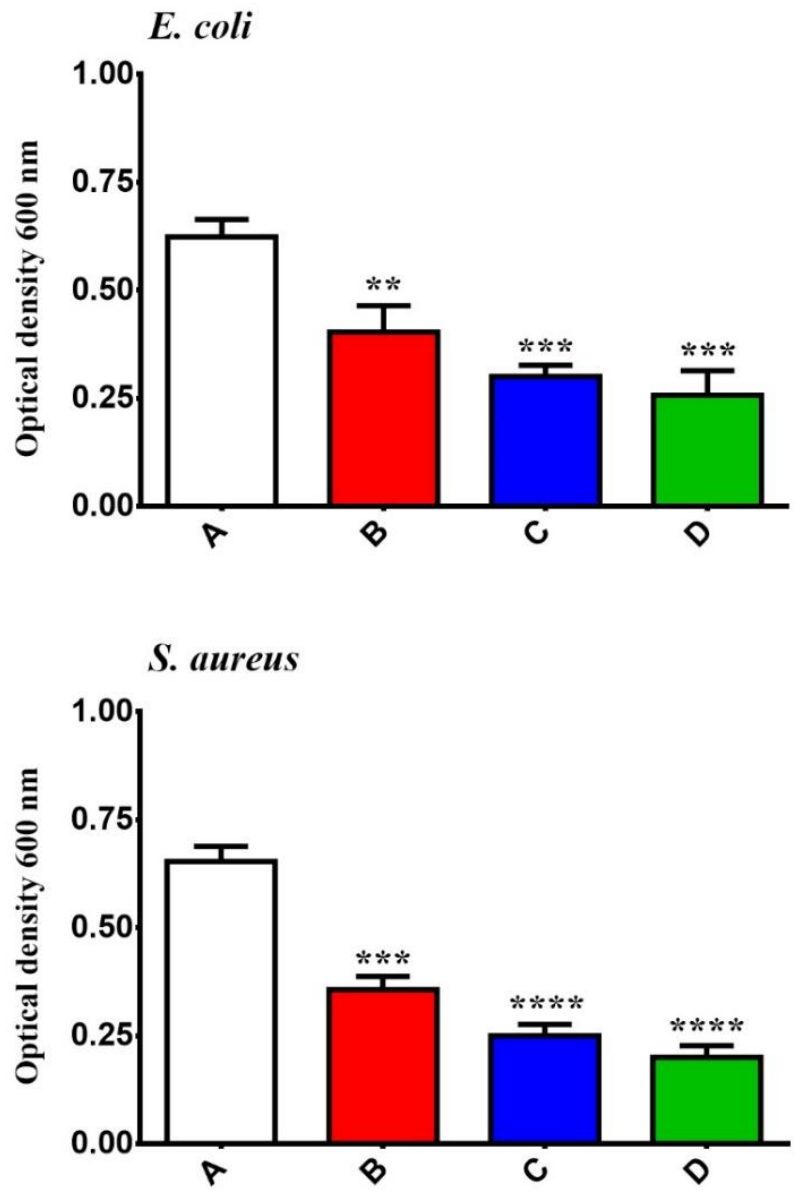

Figure 8. Effect of GONPs, GONPs-PEG and GONPs-PEG-N. stiva in the growth rate of S. aureus and E. coli. cell (A), bacterial cells treated with GONPs (B), with GONPs-PEG (C), and with GONPsPEG-N. sativa (D). The data are shown as the mean \pm SD. ${ }^{* *} p<0.01,{ }^{* * *} p<0.001$, and ${ }^{* * * *} p<0.0001$.

\subsection{Bacterial Morphology}

The effect of GONPs, GONPs-PEG, GONPs-PEG-N. sativa on the structure of organisms under treatment was assessed using the SEM technique. The images demonstrated that there were differences in the bacteria cell morphology between treated samples GONPs, GONPs-PEG, GONPs-PEG-N. sativa and the untreated samples (control). Untreated control bacterial strain E. coli SEM images confirmed the presence of cells as rod-form colonies as in Figure 9A. Since S. aureus is Gram-positive bacteria, and thus, exists in clusters, SEM images demonstrated that they were destroyed after they were treated with GONPs, GONPs-PEG, GONPs-PEG-N. sativa and as shown in Figure 9. The GONPs were observed to have moderate activities on bacterial strains as demonstrated in the bacterial cell structural changes in Figure 9B. The GONPs-PEG had more effect on the tested microorganisms' outer membrane, as it was observed that the bacterial strain cell membrane had more pores when it was treated with GONPs-PEG. The damage occurred as a result of osmotic imbalance leading to a leak of bacterial cells and it resulted in changes in morphology, osmotic balance, and cells' structural integrity after it was treated with GONPs-PEG as in Figure 9C. Furthermore, GONPs-PEG-N. sativa had higher damage in bacterial strains as shown in Figure 9D. It was observed that in the bacterial strains treated with GONPs, GONPs-PEG, GONPs-PEG-N. sativa there was aggregation and membrane rupture compared to the untreated strains. 
E. coli

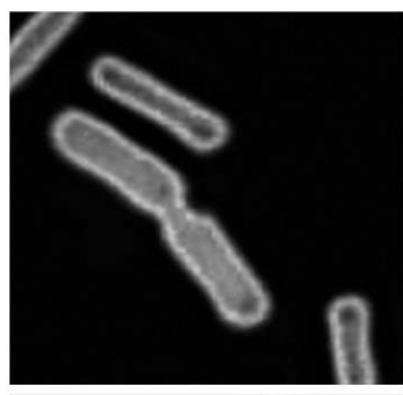

$\mathbf{A}$

B
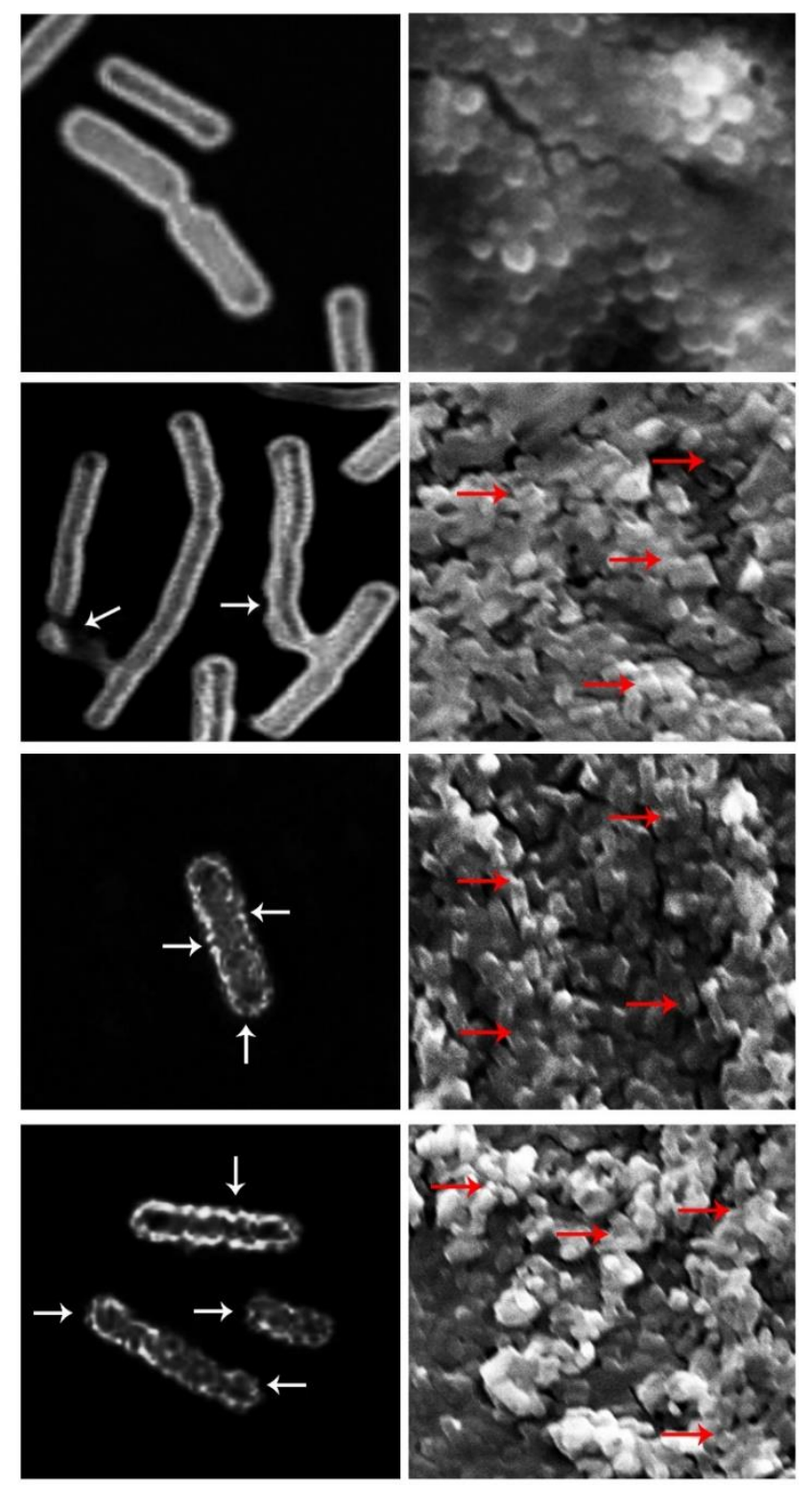

S.aureus

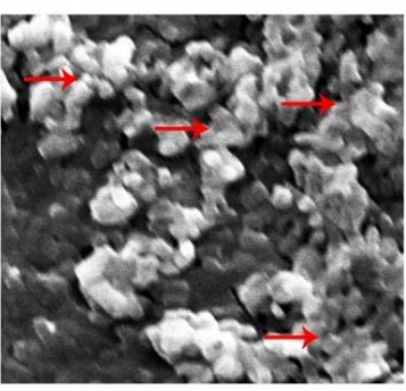

Figure 9. SEM images visualized the effect of GONPs, GONPs-PEG, and GONPs-PEG-N. sstiva on treated S. aureus and E. coli. The bacterial strains showed changes in the cell membranes like damaged, blabbed, and clumped membranes. Non-treated bacterial cell (A), bacterial cells treated with GONPs (B), with GONPs-PEG (C), and with GONPs-PEG-N. sativa (D).

\subsection{GONPS, GONPS-PEG and GONPS-PEG-N. sativa Induces Production of ROS}

The $\mathrm{AO} / \mathrm{EtBr}$ staining technique was used to detect the presence of ROS after the bacterial strains were treated with GONPs, GONPs-PEG, GONPs-PEG-N. sativa. The indicators that show the presence of ROS are nitric oxide and hydrogen peroxide. When $\mathrm{AO} / \mathrm{EtBr}$ dye comes into contact with reactive oxygen species, produced when an organism is under stress, it undergoes oxidation. The EtBr component will only pervade cells whose membrane integrity has been damaged and reacts with cells nucleic acid. The dead cells are stained in red while the viable cells are stained green [34,35]. The bacterial strains that were treated with GONPs, GONPs-PEG demonstrated moderate malformations compared to the untreated cells as present in Figure 10B,C. The GONPs-PEG-N. sativa treated bacterial stains resulted in more structural deformities as well as higher levels of ROS production as in Figure 10D, as demonstrated by a high number of bacteria strains that 
are reddish. Overall, the results showed that GONPs, GONPs-PEG, GONPs-PEG-N. sativa were suitable as antibacterial agents that can be applied in biomedical and biological fields.

A
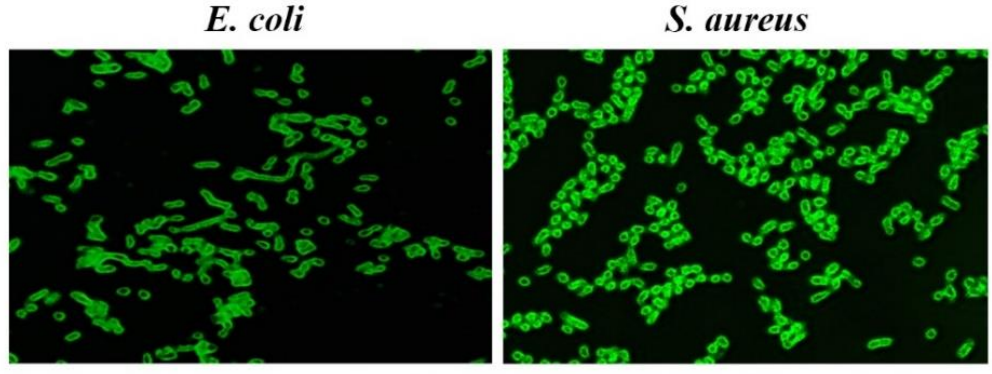

B
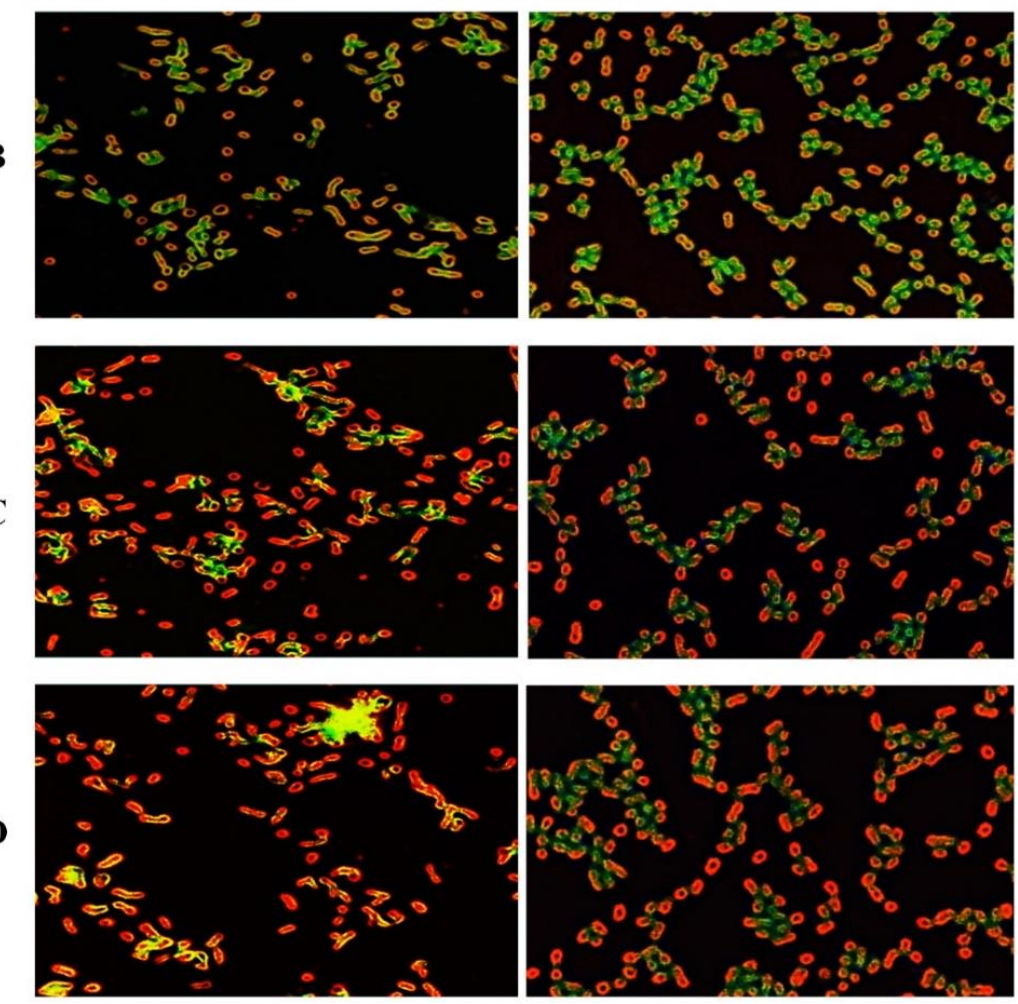

Figure 10. Fluorescence microscopic images of the green and red fluorescence stained S. aureus and E. coli. (A): non-treated bacterial strains. Bacterial cells treated with; (B) GONPs, (C): GONPs-PEG and (D): GONPs-PEG-N. sativa.

3.8. GONPS, GONPS-PEG and GONPS-PEG-N. sativa Attenuated Invasion of Bacterial Strains to REF Cells

REF cells underwent pretreatment with GONPs, GONPs-PEG, GONPs-PEG-N. sativa for an hour at a concentration of $100 \mu \mathrm{g} / \mathrm{mL}$ and then the bacterial strains were used to infect the cells at MOI (200:1). It was observed that the GONPs, GONPs-PEG, GONPsPEG-N. sativa resulted in the attenuation of bacterial strains binding to REF cells as shown in Figure 11. To determine whether GONPs, GONPs-PEG, GONPs-PEG-N. sativa also can hinder bacterial strains invasion, REF cells were pretreated GONPs, GONPs-PEG, GONPs-PEG-N. sativa at a concentration of $100 \mu \mathrm{g} / \mathrm{mL}$ for an hour and then they were infected with bacterial strains for three hours. It was observed that there was a significant decrease of cell invasion of bacterial strains in the presence and absence of GONPs, GONPsPEG, GONPs-PEG-N. sativa as shown in Figure 12. Taken together, these results of the present study demonstrated that the GONPs, GONPs-PEG, GONPs-PEG-N. sativa plays a mediation role in the invasion and adherence of bacterial strain in REF cells, and these findings are consistent with previous studies [36]. 
E. coli

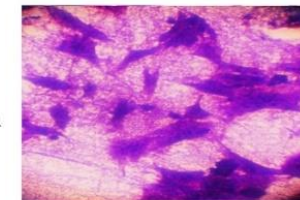

B
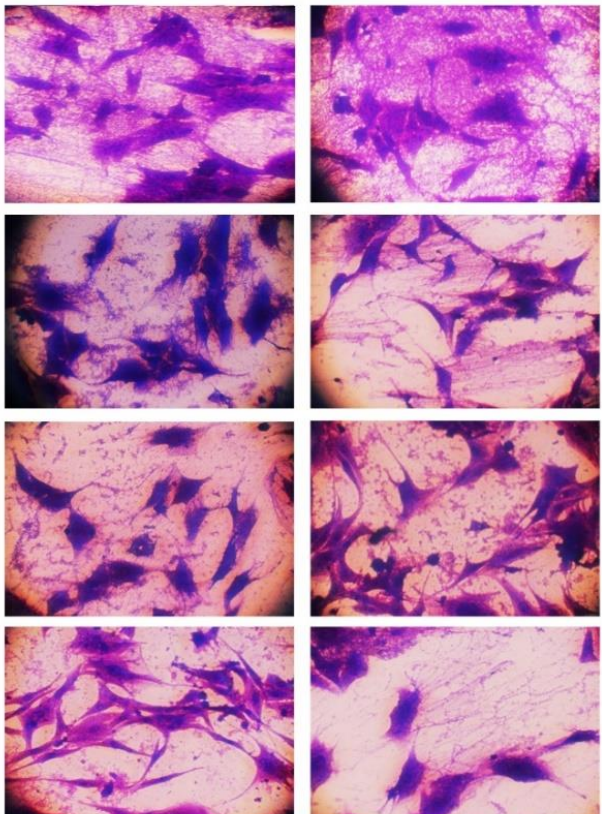

Figure 11. GONPs, GONPs-PEG and GONPs-PEG-N. sstiva inhibits invasion of bacterial strains in REF cells as indicated; (A): control REF cells infected with bacterial strains, (B): REF cells pre-treated with GONPs then infected with bacterial strains, (C): REF cells pre-treated with GONPs-PEG then infected with bacterial strains, (D): REF cells pre-treated with GONPs-PEG-N. sativa then infected with bacterial strains.
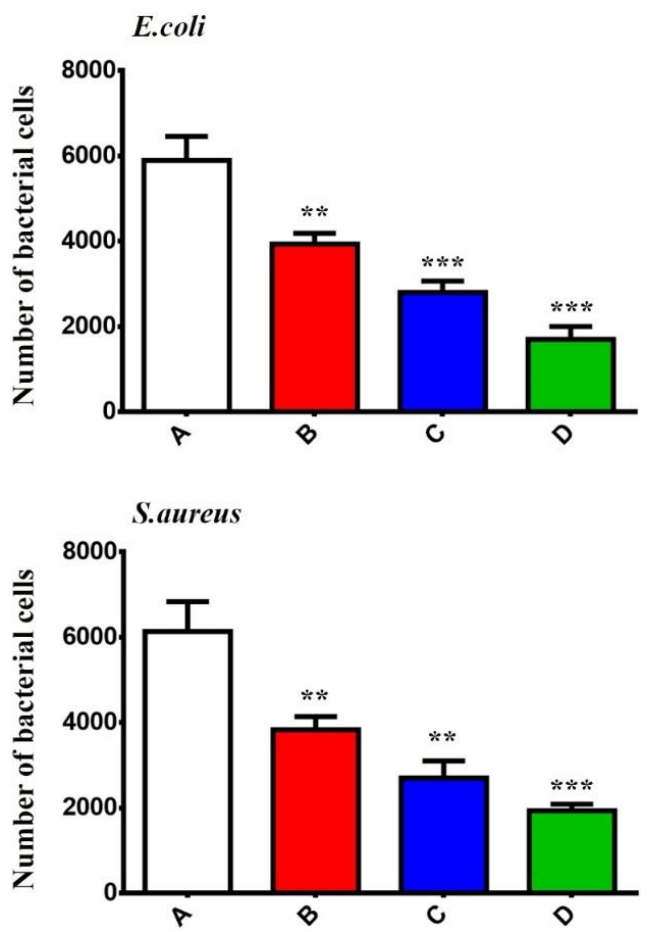

Figure 12. Illustrates the decrease interaction of bacterial strains with REF cells pre-treated with GONPs, GONPs-PEG, and GONPs-PEG-N. sativa. (A): control REF cells infected with bacterial strains, (B): REF cells pre-treated with GONPs then infected with bacterial strains, (C): REF cells pre-treated with GONPs-PEG then infected with bacterial strains, (D): REF cells pre-treated with GONPs-PEG-N. sativa then infected with bacterial strains. The values are shown as the mean $\pm \mathrm{SEM}$. ** $p<0.005,{ }^{* * *} p<0.001$. 


\section{Conclusions}

In conclusion, flaky single-layer graphene oxide (GO) synthesis by Hummer's method using rod graphite, polyethylene glycol (PEG4000) was capped with GONPs. This reaction happened between the graphene oxide (GO) carboxylic acid group and the polyethylene glycol (PEG) hydroxyl group to active (GO-COOH) using organic material and the results are GONPs-PEG smart drug delivery. The drug-loaded by Nigella sativa to get GONPs-PEG-N. sativa. This study investigated the antibacterial activity of functionalized graphene oxide with PEG4000 loading Nigella sativa. From the results the loading drug GONPs- PEG-N. sativa showed inhibitory more than GONPs and functionalized GONPs-PEG. The nanoparticles exhibited more activity in S. aureus as compared to the E. coli. Our study demonstrated that the preparation and characterization of the GONPs, functionalized nanoparticles GONP-PEG, and drug GONPs-PEG-N. sativa was successful and demonstrated a potential antibacterial activity against both S. aureus and E. coli.

Author Contributions: Conceptualization, M.A.J., and F.T.M.N.; methodology, M.A.J.; software, F.T.M.N.; validation, F.A.A., S.A., and A.A.A.; formal analysis, M.A.J.; investigation, M.S.J.; resources, F.T.M.N.; data curation, F.A.A.; writing original draft preparation, M.A.J.; writing-review and editing, S.A.; visualization, A.A.A.; supervision, M.S.J.; project administration, M.S.J. All authors have read and agreed to the published version of the manuscript.

Funding: This research received no external funding.

Institutional Review Board Statement: The study was conducted according to the guidelines of the Declaration of Helsinki, and approved by the Institutional Review Board of the University of Technology, Baghdad, Iraq (Ref. No. AS 20-8-01-2020).

Informed Consent Statement: Not applicable.

Data Availability Statement: Not applicable.

Acknowledgments: The authors extend their appreciation to the University of Technology, University of Misan, University of Baghdad, and the technical support of Taif University, Researchers Supporting Project number (TURSP-2020/274) for paying the article processing charge.

Conflicts of Interest: The authors declare no conflict of interest.

\section{Abbreviations}

GONP graphene oxide nanoparticles

GONPs-PEG graphene oxide nanoparticles-polyethylene glycol

\section{References}

1. Chung, C.; Kim, Y.-K.; Shin, D.; Ryoo, S.-R.; Hong, B.H.; Min, D.-H. Biomedical applications of graphene and graphene oxide. Acc. Chem. Res. 2013, 46, 2211-2224. [CrossRef]

2. Sun, J.; Deng, Y.; Li, J.; Wang, G.; He, P.; Tian, S.; Bu, X.; Di, Z.; Yang, S.; Ding, G. A new graphene derivative: Hydroxylated graphene with excellent biocompatibility. ACS Appl. Mater. Interfaces 2016, 8, 10226-10233. [CrossRef]

3. Yang, G.; Zhu, C.; Du, D.; Zhu, J.; Lin, Y. Graphene-like two-dimensional layered nanomaterials: Applications in biosensors and nanomedicine. Nanoscale 2015, 7, 14217-14231. [CrossRef]

4. Mohajeri, M.; Behnam, B.; Sahebkar, A. Biomedical applications of carbon nanomaterials: Drug and gene delivery potentials. J. Cell. Physiol. 2019, 234, 298-319. [CrossRef]

5. Jiang, L.; Su, C.; Ye, S.; Wu, J.; Zhu, Z.; Wen, Y.; Zhang, R.; Shao, W. Synergistic antibacterial effect of tetracycline hydrochloride loaded functionalized graphene oxide nanostructures. Nanotechnology 2018, 29, 505102. [CrossRef] [PubMed]

6. Bugli, F.; Cacaci, M.; Palmieri, V.; Di Santo, R.; Torelli, R.; Ciasca, G.; Di Vito, M.; Vitali, A.; Conti, C.; Sanguinetti, M. Curcuminloaded graphene oxide flakes as an effective antibacterial system against methicillin-resistant Staphylococcus aureus. Interface Focus 2018, 8, 20170059. [CrossRef] [PubMed]

7. Chen, Y.-W.; Su, Y.-L.; Hu, S.-H.; Chen, S.-Y. Functionalized graphene nanocomposites for enhancing photothermal therapy in tumor treatment. Adv. Drug Deliv. Rev. 2016, 105, 190-204. [CrossRef] [PubMed]

8. D'souza, A.A.; Shegokar, R. Polyethylene glycol (PEG): A versatile polymer for pharmaceutical applications. Expert Opin. Drug Deliv. 2016, 13, 1257-1275. [CrossRef] 
9. Abdel-Fattah, A.-F.M.; Matsumoto, K.; Watanabe, H. Antinociceptive effects of Nigella sativa oil and its major component, thymoquinone, in mice. Eur. J. Pharmacol. 2000, 400, 89-97. [CrossRef]

10. Ali, B.; Blunden, G. Pharmacological and toxicological properties of Nigella sativa. Phytother. Res. Int. J. Devoted Pharmacol. Toxicol. Eval. Nat. Prod. Deriv. 2003, 17, 299-305. [CrossRef]

11. Bahjat, H.H.; Ismail, R.A.; Sulaiman, G.M.; Jabir, M.S. Magnetic Field-Assisted Laser Ablation of Titanium Dioxide Nanoparticles in Water for Anti-Bacterial Applications. J. Inorg. Organomet. Polym. Mater. 2021. [CrossRef]

12. Al-Musawi, S.; Albukhaty, S.; Al-Karagoly, H.; Sulaiman, G.M.; Alwahibi, M.S.; Dewir, Y.H.; Soliman, D.A.; Rizwana, H. Antibacterial Activity of Honey/Chitosan Nanofibers Loaded with Capsaicin and Gold Nanoparticles for Wound Dressing. Molecules 2020, 25, 4770. [CrossRef]

13. Khashan, K.S.; Sulaiman, G.M.; Hussain, S.A.; Marzoog, T.R.; Jabir, M.S. Synthesis, characterization and evaluation of antibacterial, anti-parasitic and anti-cancer activities of aluminum-doped zinc oxide nanoparticles. J. Inorg. Organomet. Polym. Mater. 2020, 30, 3677-3693. [CrossRef]

14. Kadhim, W.K.A.; Nayef, U.M.; Jabir, M.S. Polyethylene glycol-functionalized magnetic $\left(\mathrm{Fe}_{3} \mathrm{O}_{4}\right)$ nanoparticles: A good method for a successful antibacterial therapeutic agent via damage DNA molecule. Surface Rev. Lett. 2019, 26, 1950079. [CrossRef]

15. Jabir, M.S.; Nayef, U.M.; Kadhim, W.K.A. Polyethylene glycol-functionalized magnetic $\left(\mathrm{Fe}_{3} \mathrm{O}_{4}\right)$ nanoparticles: A novel DNAmediated antibacterial agent. Nano Biomed. Eng. 2019, 11, 18-27. [CrossRef]

16. Younus, A.; Al-Ahmer, S.; Jabir, M. Evaluation of some immunological markers in children with bacterial meningitis caused by Streptococcus pneumoniae. Res. J. Biotechnol. 2019, 14, 131-133.

17. Jabir, M.S.; Nayef, U.M.; Jawad, K.H.; Taqi, Z.J.; Ahmed, N.R. Porous silicon nanoparticles prepared via an improved method: A developing strategy for a successful antimicrobial agent against Escherichia coli and Staphylococcus aureus. In Proceedings of the 1st International Conference on Materials Engineering and Science, Istanbul, Turkey, 8-9 August 2018; Volume 454, p. 012077.

18. Albukhaty, S.; Naderi-Manesh, H.; Tiraihi, T. In vitro labeling of neural stem cells with poly-L-lysine coated super paramagnetic nanoparticles for green fluorescent protein transfection. Iran. Biomed. J. 2013, 17, 71-76. [PubMed]

19. Wintachai, P.; Paosen, S.; Yupanqui, C.T.; Voravuthikunchai, S.P. Silver nanoparticles synthesized with Eucalyptus critriodora ethanol leaf extract stimulate antibacterial activity against clinically multidrug-resistant Acinetobacter baumannii isolated from pneumonia patients. Microb. Pathog. 2019, 126, 245-257. [CrossRef]

20. Kareem, S.H.; Naji, A.M.; Taqi, Z.J.; Jabir, M.S. Polyvinylpyrrolidone Loaded-MnZnFe2O4 Magnetic Nanocomposites Induce Apoptosis in Cancer Cells Through Mitochondrial Damage and P 53 Pathway. J. Inorg. Organomet. Polym. Mater. 2020, 30, 5009-5023. [CrossRef]

21. Ali, S.H.; Sulaiman, G.M.; Al-Halbosiy, M.M.; Jabir, M.S.; Hameed, A.H. Fabrication of hesperidin nanoparticles loaded by poly lactic co-Glycolic acid for improved therapeutic efficiency and cytotoxicity. Artif. Cells Nanomed. Biotechnol. 2019, 47, 378-394. [CrossRef]

22. Zhou, L.Y.; Zhu, Y.H.; Wang, X.Y.; Shen, C.; Wei, X.W.; Xu, T.; He, Z.Y. Novel zwitterionic vectors: Multi-functional delivery systems for therapeutic genes and drugs. Comput. Struct. Biotechnol. J. 2020, 18, 1980-1999. [CrossRef] [PubMed]

23. Charmi, J.; Nosrati, H.; Amjad, J.M.; Mohammadkhani, R.; Danafar, H. Polyethylene glycol (PEG) decorated graphene oxide nanosheets for controlled release curcumin delivery. Heliyon 2019, 5, e01466. [CrossRef] [PubMed]

24. Jabir, M.S.; Sulaiman, G.M.; Taqi, Z.J.; Li, D. Iraqi propolis increases degradation of IL-1 $\beta$ and NLRC4 by autophagy following Pseudomonas aeruginosa infection. Microbes Infect. 2018, 20, 89-100. [CrossRef] [PubMed]

25. Wang, C.; Feng, L.; Yang, H.; Xin, G.; Li, W.; Zheng, J.; Tian, W.; Li, X. Graphene oxide stabilized polyethylene glycol for heat storage. Phys. Chem. Chem. Phys. 2012, 14, 13233-13238. [CrossRef] [PubMed]

26. Badrzadeh, F.; Akbarzadeh, A.; Zarghami, N.; Yamchi, M.R.; Zeighamian, V.; Tabatabae, F.S.; Taheri, M.; Kafil, H.S. Comparison between effects of free curcumin and curcumin loaded NIPAAm-MAA nanoparticles on telomerase and PinX1 gene expression in lung cancer cells. Asian Pac. J. Cancer Prev. 2014, 15, 8931-8936. [CrossRef]

27. Kumar, N.; Das, S.; Bernhard, C.; Varma, G. Effect of graphene oxide doping on superconducting properties of bulk MgB2. Supercond. Sci. Technol. 2013, 26, 095008.

28. Leite, A.B.; Saucier, C.; Lima, E.C.; Dos Reis, G.S.; Umpierres, C.S.; Mello, B.L.; Shirmardi, M.; Dias, S.L.; Sampaio, C.H. Activated carbons from avocado seed: Optimisation and application for removal of several emerging organic compounds. Environ. Sci. Pollut. Res. 2018, 25, 7647-7661. [CrossRef]

29. Zhang, Y.; Shareena Dasari, T.P.; Deng, H.; Yu, H. Antimicrobial Activity of Gold Nanoparticles and Ionic Gold. J. Environ. Sci. Health Part C Environ. Carcinog. Ecotoxicol. Rev. 2015, 33, 286-327. [CrossRef] [PubMed]

30. Burygin, G.L. On the enhanced antibacterial activity of antibiotics mixed with gold nanoparticles. Nanoscale Res. Lett. 2009, 4, 794-801. [CrossRef]

31. Albukhaty, S.; Al-Bayati, L.; Al-Karagoly, H.; Al-Musawi, S. Preparation and characterization of titanium dioxide nanoparticles and in vitro investigation of their cytotoxicity and antibacterial activity against Staphylococcus aureus and Escherichia coli. Anim. Biotechnol. 2020. [CrossRef]

32. Albukhaty, S.; Al-Karagoly, H.; Dragh, M.A. Synthesis of Zinc Oxide Nanoparticles and Evaluated It's Activity Against Bac-terial Isolates. J. Biotech. Res. 2020, 11, 47-53.

33. Nivetha, K.; Prasanna, G. GC-MS and FT-IR analysis of Nigella sativa L. seeds. Int. J. Adv. Res. Biol. Sci. 2016, 3, 45-54. 
34. Belete, Y.; Dagne, E. HPTLC assay of thymoquinone in black seed and black seed oil (Nigella Sativa Linn) and identification of thymoquinone conversion with Uv-Vis. J. Drug Deliv. Ther. 2014, 4, 5-9. [CrossRef]

35. Karthikeyan, S.; Ahmed, K.; Osatiashtiani, A.; Lee, A.F.; Wilson, K.; Sasaki, K.; Coulson, B.; Swansborough-Aston, W.; Douthwaite, R.E.; Li, W. Pompon Dahlia-like $\mathrm{Cu}_{2} \mathrm{O}$ /rGO Nanostructures for Visible Light Photocatalytic $\mathrm{H}_{2}$ Production and 4-Chlorophenol Degradation. ChemCatChem 2020, 12, 1699-1709. [CrossRef]

36. Chahardoli, A.; Karimi, N.; Fattahi, A. Biosynthesis, characterization, antimicrobial and cytotoxic effects of silver nanoparticles using Nigella arvensis seed extract. Iran. J. Pharm. Res. 2017, 16, 1167-1175. 